\section{Responses of Creeping Bentgrass to Salinity and Mowing Management: Growth and Turf Quality}

\author{
J.M. Fu, A.J. Koski, and Y.L. Qian* \\ Department of Horticulture and Landscape Architecture, Colorado State \\ University, Fort Collins, CO 80523-1173
}

\begin{abstract}
Salt problems in turfgrass sites are becoming more common. The effects of mowing management on salinity tolerance are not well understood. The objective of this study was to examine the effects of three mowing regimes on turf quality and growth responses of ' $\mathrm{L}-93$ ' creeping bentgrass (Agrostis palustris $\mathbf{L}$.) to salinity stress. Sods of ' $\mathrm{L}$ 93 ' creeping bentgrass were grown in containers $(45 \mathrm{~cm}$ long and $10 \mathrm{~cm}$ in diameter) in a greenhouse. Treatments included three mowing regimes (clipping three times weekly at $\mathbf{2 5 . 4} \mathbf{~ m m}$, four times at $12.7 \mathrm{~mm}$, and daily at $6.4 \mathrm{~mm}$ ) and four levels of irrigation water salinity (control, 5,10 , and $15 \mathrm{dS} \cdot \mathrm{m}^{-1}$ ). The relationship of increasing soil salinity with increasing irrigation water salinity was linear in each soil layer. Increasing salinity reduced turf quality and clipping yield more severely and rapidly when mowed at $6.4 \mathrm{~mm}$ than at 12.7 or $25.4 \mathbf{~ m m}$. Regression analysis of soil salinity and turf quality suggested that turf quality of creeping bentgrass mowed to $6.4,12.7$, and $25.4 \mathrm{~mm}$ fell to an unacceptable level when soil salinity reached $4.1,12.5$, and $13.9 \mathrm{dS} \cdot \mathrm{m}^{-1}$, respectively. Data on turf quality, clipping yield, and verdure indicated that salinity damage becomes more severe under close mowing conditions and that a moderate increase in mowing height could improve salinity tolerance of creeping bentgrass.
\end{abstract}

Salt problems in turfgrass sites are becoming more common for many reasons: accelerated urban development in western states where saline soils are common; the use of wastewater or other irrigation waters containing sodium and other salts, seawater intrusion into turf facilities located on coastal sites, and road deicing. Drought and water shortages result in mandatory turf watering restrictions in many cities. Water conservation efforts can further increase soil salinity levels due to reduced leaching.

Creeping bentgrass, because of its high turf quality and recuperative ability, is one of the most widely used species on golf course putting greens, tees, and fairways in the United States. The salinity tolerance of creeping bentgrass has been ranked from moderately sensitive [tolerant of 3 to $6 \mathrm{dS} \cdot \mathrm{m}^{-1}$ salinity of saturated soil paste (ECe)] to moderately tolerant (tolerant of 8 to $16 \mathrm{dS} \cdot \mathrm{m}^{-1} \mathrm{ECe}$ ) (Beard, 1973; Carrow and Duncan, 1998; Harivandi et al., 1992). A decline in bentgrass quality is often observed under salinity stress and close mowing conditions on putting greens and tees (personal observation). In addition to varietal variations (Marcum, 2001), different mowing regimes may also contribute to the great variations in salinity tolerance reported for creeping bentgrass. Reduced mowing height has been found to reduce turf quality (Salaiz et al., 1995), root production (Krans and Beard, 1975; Salaizetal., 1995), photosynthesis(Hull, 1987; Krans and Beard, 1975; Liu and Huang,

Received for publication 6 May 2004. Accepted for publication 19 Aug. 2004. The research was supported by the O.J. Noer Research Foundation and the Colorado Agricultural Experimental Station (Project 780).

${ }^{1}$ Corresponding author; e-mailYaling.Qian@colostate. edu.
2003), and total nonstructural carbohydrate content (Huang and Fry, 1999).

No published information is available to address the influence of mowing height and frequency on creeping bentgrass salinity tolerance. Most studies comparing salinity tolerance among different grasses have been conducted under a single mowing regime or under un-mowed conditions (Qian et al., 2004; Youngner et al., 1967). We hypothesize that close mowing will reduce the salinity tolerance of turfgrass because mowing reduces rooting, ability. Close mowing may also reduce energy reserves, thereby reducing the salt-coping ability of turfgrass. Studies with other plants have shown that many salt resistance mechanisms (salt exclusion, salt secretion, salt sequestration, synthesis of benign osmoprotectants, salt damage repair, etc) are energy dependent (Tester and Davenport, 2003).

Understanding the interactive effects of mowing and salinity on turfgrass growth will aid in the development of guidelines for effective mowing practices that promote maximum salt tolerance in turfgrass. The objective of this study was to examine the effects of three mowing regimes on turf quality and growth responses of 'L-93' creeping bentgrass to salinity stress.

\section{Materials and Methods}

Plant materials and growth conditions. Sod pieces ( $10 \mathrm{~cm}$ in diameter) of 'L-93' were collected from a putting green at the Horticulture Research Center, Fort Collins, Colo. After removing soil by hand washing, sod pieces were transplanted to polyvinyl chloride (PVC) tubes ( $45 \mathrm{~cm}$ long and $10 \mathrm{~cm}$ in diameter) that were packed with clay loam soil to a uniform bulk density and kept in a greenhouse. thereby negating the plant's water extracting
Plants were grown in the PVC tubes for 2 months, allowing root and canopy to establish before treatments were imposed. During this period, plants were watered on alternate days until water drained freely from the holes at the bottom of each tube and fertilized weekly with Peters Excel solution (15N-2P-12K, ScottsSierra Horticultural Products Co., Marysville, Ohio) to provide $24 \mathrm{~kg} \mathrm{~N} / \mathrm{ha} / \mathrm{month}$. Each turf was hand-clipped every $2 \mathrm{~d}$ at $6.4 \mathrm{~mm}$. The daily maximal/minimal temperatures in the greenhouse were $22 / 18^{\circ} \mathrm{C}$. Photosynthetically active radiation on a horizontal plane just above the canopy at 10:00 HR averaged about 1000 $\mu \mathrm{mol} \cdot \mathrm{m}^{-2} \cdot \mathrm{s}^{-1}$.

Treatments. Salinity treatments were applied by irrigating with different concentrations of saline water. Irrigation waters of different salinity levels were prepared by the addition of ocean salts (Aquarium Systems, Mentor, Ohio) to tap water to obtain EC values of 0.2 (control), 5.0, 10.0, and $15.0 \mathrm{dS} \cdot \mathrm{m}^{-1}$, measured by an electrical conductivity meter (model CO150; Hach Co., Loveland, Colo.). Mowing treatments included clipping three times weekly at $25.4 \mathrm{~mm}$, four times at $12.7 \mathrm{~mm}$, and daily at $6.4 \mathrm{~mm}$. Irrigation was applied every $2 \mathrm{~d}$ with an amount equal to $120 \%$ of evapotranspiration (ET), as measured with an extra PVC container (served as a lysimeter) of bentgrass mowed at $25.4 \mathrm{~mm}$. The amount of water applied was the same for all salinity and mowing treatments.

Measurements. Data were collected on turf quality, clipping yield, verdure, root dry weight, and soil salinity level. Visual turf quality was rated biweekly based on color, density, and uniformity using a scale of 0 (brown, dead turf) to 9 (optimum color, density, and uniformity), with a rating of 6.0 or higher indicating acceptable quality. Clipping yield was determined once every two weeks by collecting clippings grown during the previous 1 or 2 days, determining oven-dried (at $70{ }^{\circ} \mathrm{C}$ for $48 \mathrm{~h}$ ) mass, and then calculating daily growth.

Verdure, root mass at different depths, and soil salinity at different depths were determined at the termination of the experiment. Aboveground tissue (verdure) was harvested, freezedried immediately (Genesis 25LL lyophilizer; Virtis, Gardiner, N.Y.), and weighed. The PVC tubes containing soil were cut into four $10-\mathrm{cm}$ deep sections. One-fourth of the soil within each section was air-dried for the measurement of soil salinity. Roots in the rest of the soil were washed free of soil, freeze-dried, and weighed.

To determine soil salinity, the air-dried soil was crushed and passed through a $2-\mathrm{mm}$ soil sieve. Electrical conductivity of saturated soil paste was determined with the Hach soil salinity appraisal kit (model CO150; Hach Co.). The mean root zone salinity for each column was calculated using a method described by Devitt (1989).

Statistical analysis. Asplit-plot experimental design was used with salinity treatment being the main plot, and mowing regimes being the subplots. Each treatment had four replications. Effects of mowing, salinity, and their interaction were determined by analysis 
of variance (SAS Institute, 2001). Turf quality and clipping yield were analyzed on individual measurement dates to examine salinity and mowing effects over time. Because the significant interaction of mowing regime and salinity level was often observed, comparisons of salinity treatments within individual mowing regimes are presented and means were separated by least significant difference at the 0.05 level of probability. Regression analysis was performed to determine the relationship between the parameters measured at the termination of the study and the mean root zone salinity (integrated soil salinity), where salinity was the independent variable and each measured parameter was the dependent variable.

\section{Results and Discussion}

Soil salinity. Irrigation with 4 different concentrations of saline water caused dramatically different soil salinity levels (Fig. 1). A linear relationship of increasing soil salinity with increasing irrigation water salinity was achieved in each soil layer $\left(R^{2}=0.92\right.$ to 0.99$)$.

Different mowing regimes had little effect on soil salinity when turf was irrigated with non-saline water (Fig. 1). When irrigated with 5 to $15 \mathrm{dS} \cdot \mathrm{m}^{-1}$ water, decreasing mowing height and increasing mowing frequency caused a reduction in soil salinity. Soil salinity was significantly higher for the $25.4 \mathrm{~mm}$ mowing regime than for the $6.4 \mathrm{~mm}$ mowing regime at all depths of the soil profile. When irrigated with $5 \mathrm{dS} \cdot \mathrm{m}^{-1}$ water, soil salinity was higher for the $25.4 \mathrm{~mm}$ mowing regime than for $12.7 \mathrm{~mm}$ mowing regime at all depths. When irrigated with $10 \mathrm{dS} \cdot \mathrm{m}^{-1}$ water, soil salinity was higher at $12.7 \mathrm{~mm}$ mowing height when compared to $6.4 \mathrm{~mm}$ mowing height. The higher soil salinity observed under higher mowing heights likely have occurred because turf mowed at higher heights possessed higher ET rates. Since we irrigated each treatment with the same amount of water, a higher mowing height likely resulted in a lower leaching fraction than the low mowing height. The leaching fraction was $20 \%$ for nonsaline treatment at $25.4 \mathrm{~mm}$ mowing regime. The amount of water leached increased as salinity increased and mowing height reduced due to reduced ET. Considering the difference in soil salinity under different mowing regimes, the relationship between bentgrass quality and shoot growth vs. soil salinity presented in Table 1 provided good indications of the effect of soil salinity on creeping bentgrass at different mowing heights.

As the salinity increased in irrigation water, the trend of increasing soil salinity with depth became apparent under high mowing regime. This trend was not apparent under conditions of low irrigation water salinity and /or low mowing height (i.e., high leaching fraction) conditions.

Turf quality. At the starting point of mowing and salinity treatments, all tubes exhibited a desirable turf quality (turf quality $=9$ ). Turf quality declined over time with increasing salinity (Fig. 2). However, the quality decline caused by increasing salinity was more severe and more rapid when mowed at $6.4 \mathrm{~mm}$ than at 12.7 or $25.4 \mathrm{~mm}$. When mowed to $6.4 \mathrm{~mm}$, irrigation with saline waters at 5, 10, and 15 $\mathrm{dS} \cdot \mathrm{m}^{-1}$ resulted in quality decline to an unacceptable level at 73, 60, and $30 \mathrm{~d}$ after treatment, respectively.

When mowed to 12.7 and $25.4 \mathrm{~mm}$ and irrigated with saline water at 5 and $10 \mathrm{dS} \cdot \mathrm{m}^{-1}$, creeping bentgrass maintained turf quality above 6 throughout the study period. Yet, irrigation with saline water at $15 \mathrm{dS} \cdot \mathrm{m}^{-1}$ reduced turf quality to an unacceptable level beginning $73 \mathrm{~d}$ after treatment.

Regression analysis was conducted to generate the relationship between soil salinity and turf quality at $85 \mathrm{~d}$ after salinity treatment. The linear equation presented in Table 1 suggests that with each unit increase in soil salinity, the turf quality reduction slope was significantly high for the lowest mowing height. Using these equations, we predict that turf quality of creeping bentgrass mowed to $6.4,12.7$, and $25.4 \mathrm{~mm}$ will fall below 6 when soil salinity reaches $4.1,12.5$, and $13.9 \mathrm{dS} \cdot \mathrm{m}^{-1}$, respectively, under these growing conditions. Turf quality data suggests that salinity damage becomes much more severe under shorter mowing heights.

Although creeping bentgrass is typically considered to have medium to good salt tolerance, the short mowing heights used on putting greens and tees will greatly increase the susceptibility of bentgrass to salt stress. In addition to varietal variations (Marcum, 2001), different mowing regimes may also contribute to the great variations in salinity tolerance reported for creeping bentgrass. Our results suggest that increasing mowing height could help improve bentgrass salinity tolerance.

Clippingyield. Clipping yield is one indicator of turf vigor. Clipping yield decreased over time with increasing salinity (Fig. 3). When mowed at $6.4 \mathrm{~mm}$, creeping bentgrass receiving irrigation water at 5,10 , or $15 \mathrm{dS} \cdot \mathrm{m}^{-1}$ salinity exhibited significantly lower clipping yields than the control at $30 \mathrm{~d}$ after salinity treatment and at the end of the experiment.

When mowed at $12.7 \mathrm{~mm}, 5$ and $10 \mathrm{dS} \cdot \mathrm{m}^{-1}$ irrigation water had no significant effects on clipping yield during most of experimental period. Irrigation with $15 \mathrm{dS} \cdot \mathrm{m}^{-1}$ water reduced clipping yield significantly by the end of the experiment (Fig. 3).

Bentgrass mowed at $25.4 \mathrm{~mm}$ and irrigated with 10 and $15 \mathrm{dS} \cdot \mathrm{m}^{-1}$ water had reduced clipping yield beginning at $42 \mathrm{~d}$ after salinity treatment began while irrigation with $5 \mathrm{dS} \cdot \mathrm{m}^{-1}$ water had no effect on clipping yield.

The linear relationships between average root zone salinity and clipping yield harvested at $84 \mathrm{~d}$ after the initiation of salinity treatments are presented in Table 1 . The effect of salinity on bentgrass clipping yield was most severe at the $6.4 \mathrm{~mm}$ mowing height followed by 25.4 $\mathrm{mm}$ mowing regime. Salinity had the least effect on creeping bentgrass clipping growth when mowed at $12.7 \mathrm{~mm}$. It is unclear why salinity had the least effect on clipping yield reduction at $12.7 \mathrm{~mm}$ rather than $25.4 \mathrm{~mm}$ mowing height.

In previous work, salinity levels that resulted in $25 \%$ clipping yield reduction have been used as an indicator of salinity tolerance (Qian et al., 2001, 2004; Suplick-Ploense et al., 2002). Using the regression equation in Table 1 and clipping yield for the control, $25 \%$ clipping yield reduction salinities were derived. Under the $12.7 \mathrm{~mm}$ mowing height, the salinity level that resulted in $25 \%$ clipping yield reduction was $14.0 \mathrm{dS} \cdot \mathrm{m}^{-1}$ whereas a salinity level as low as $5.7 \mathrm{dS} \cdot \mathrm{m}^{-1}$ would result in $25 \%$ clipping yield reduction of creeping bentgrass mowed to $6.4 \mathrm{~mm}$. Our results with creeping bentgrass suggest that the salinity tolerance of

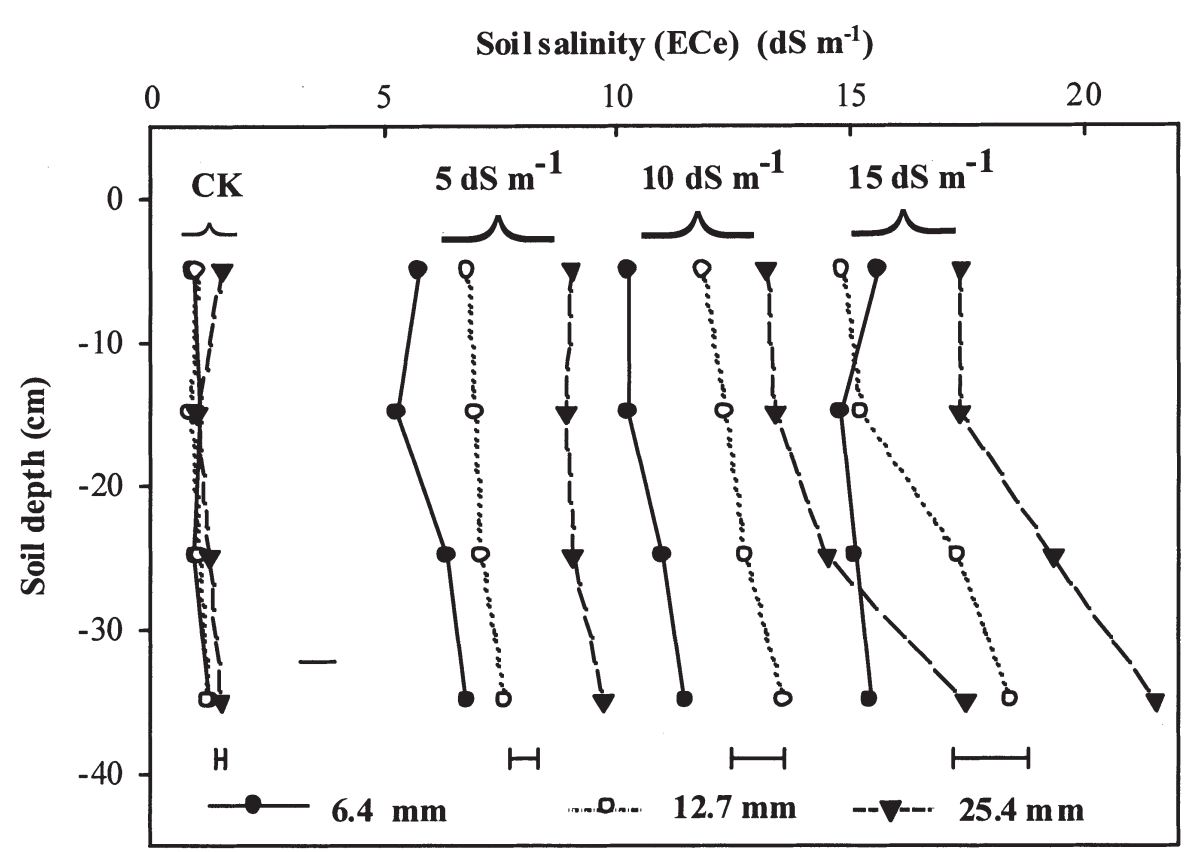

Fig. 1. Influence of mowing height and irrigation water salinity on soil salinity at 0 to 10,10 to 20,20 to 30 , and 30 to $40 \mathrm{~cm}$ below soil surface. Horizontal bars indicate LSD value $(P=0.05)$ for mowing height comparison with each salinity treatment. 


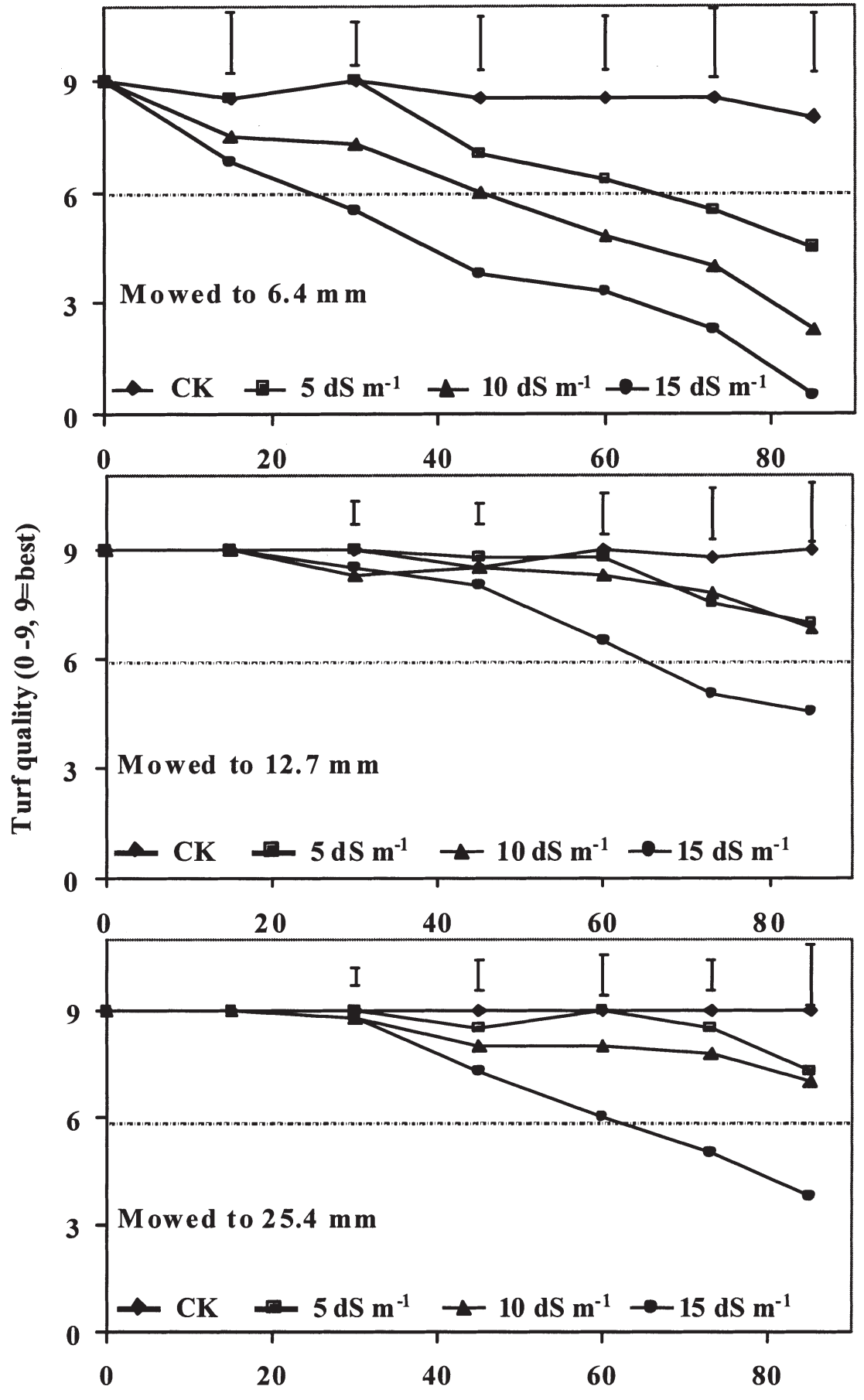

Days of treatment

Table 1. Linear regression of creeping bentgrass parameters (measured at the end of experiment, $85 \mathrm{~d}$ after treatments) vs. soil salinity.

\begin{tabular}{lclc}
\hline Parameter & $\begin{array}{c}\text { Mowing ht } \\
(\mathrm{mm})\end{array}$ & Regression & $R^{2}$ \\
\hline Quality (0-9 scale) & 6.4 & $\mathrm{Y}=-0.52 \mathrm{X}+8.15$ & $0.98^{* *}$ \\
& 12.7 & $\mathrm{Y}=-0.26 \mathrm{X}+9.23$ & $0.89^{* *}$ \\
& 25.4 & $\mathrm{Y}=-0.26 \mathrm{X}+9.65$ & $0.84^{* *}$ \\
Cliping yield (mg/tube/d) & 6.4 & $\mathrm{Y}=-1.70 \mathrm{X}+33.72$ & $0.91^{* *}$ \\
& 12.7 & $\mathrm{Y}=-0.71 \mathrm{X}+38.85$ & $0.61^{* *}$ \\
& 25.4 & $\mathrm{Y}=-1.63 \mathrm{X}+65.24$ & $0.84^{* *}$ \\
Verdure (g/tube) & 6.4 & $\mathrm{Y}=-0.09 \mathrm{X}+3.03$ & $0.23^{\mathrm{NS}}$ \\
& 12.7 & $\mathrm{Y}=0.02 \mathrm{X}+3.42$ & $0.21^{\mathrm{NS}}$ \\
& 25.4 & $\mathrm{Y}=0.01 \mathrm{X}+5.45$ & $0.01^{\mathrm{NS}}$ \\
Root mass (mg/tube) & 6.4 & $\mathrm{Y}=-1.02 \mathrm{X}+245.98$ & $0.03^{\mathrm{NS}}$ \\
& 12.7 & $\mathrm{Y}=5.92 \mathrm{X}+0.21$ & $0.49^{* *}$ \\
& 25.4 & $\mathrm{Y}=2.75 \mathrm{X}+368.68$ & $0.04^{\mathrm{NS}}$ \\
\hline
\end{tabular}

$\mathrm{NS},{ }^{* * * *}$ Nonsignificant or significant at 0.05 and 0.01 levels, respectively.
Fig. 2. Influence of irrigation water salinity on visual quality of creeping bentgrass mowed to $6.4,12.7$, and $25.4 \mathrm{~mm}$, respectively. Vertical bars indicate LSD value $(P=0.05)$ for salinity treatment comparison with a mowing height at a given day of treatment.

turfgrass will be considerably lowered under short mowing heights.

Verdure and rootmass. When mowed at 12.7 or $25.4 \mathrm{~mm}$, verdure of creeping bentgrass was unchanged as salinity increased from control to $15 \mathrm{dS} \cdot \mathrm{m}^{-1}$. However, when bentgrass was mowed at $6.4 \mathrm{~mm}$, irrigation with 5 to $15 \mathrm{dS} \cdot \mathrm{m}^{-1}$ water reduced verdure biomass by $33 \%$ to $42 \%$ when compared to the nonsaline control (Fig. 4). The reduction in verdure reflected reductions in shoot growth and turf density under close mowing and salinity stress conditions.

In agreement with previous studies (Krans and Beard, 1975; Salaiz et al., 1995), mowing height significantly affects total root mass of bentgrass (Fig. 4). When salinity of irrigation water was between the control level and 10 $\mathrm{dS} \mathrm{m}{ }^{-1}$, total root mass was $30 \%$ to $66 \%$ and $39 \%$ to $89 \%$ greater at the $25.4 \mathrm{~mm}$ mowing height than at 12.7 and $6.4 \mathrm{~mm}$ mowing regimes, respectively. When salinity of irrigation water was $15 \mathrm{dS} \cdot \mathrm{m}^{-1}$, the ranking of mowing heights for total root mass was $25.4>12.7$ $>6.4 \mathrm{~mm}$.

The highest root mass for all treatments occurred in the 0-10 cm depth, comprising $54 \%$ to $71 \%$ of the total root mass. In both the 0 to $10 \mathrm{~cm}$ and 10 to $20 \mathrm{~cm}$ depths, root mass increased with increasing mowing height. However, this trend was not as clear at 20 to 30 and 30 to $40 \mathrm{~cm}$ below the soil surface.

Root growth of bentgrass with different mowing regimes responded differently to increasing salinity. At 0 to $10 \mathrm{~cm}$, bentgrass mowed at $12.7 \mathrm{~mm}$ exhibited higher root mass under the highest salinity level when compared to the nonsaline control. A relationship of increasing total root mass with increasing salinity was significant for the $12.7 \mathrm{~mm}$ mowing regime only (Table 2). Salinity stress generally increases root growth. Marcum (1999) reported an increase in root mass of several grasses mowed to 35 to $75 \mathrm{~mm}$ under saline conditions. Root growth stimulation under saline conditions has been reported in salt tolerant grasses (Dudeck et al., 1983, Meyer et al., 1989; Peacock and Dudeck, 1985). Increased rooting, and the associated increase in root absorbing area, is an adaptive mechanism to the osmotic and nutrient deficiency stresses present under saline conditions (Rozema and Visser, 1981.)

At the 30 to $40 \mathrm{~cm}$ depth, however, bentgrass mowed to $6.4 \mathrm{~mm}$ exhibited much reduced root mass as the level of salinity increased. The failure of close-cut bentgrass to maintain root mass at 30 to $40 \mathrm{~cm}$ with increasing salinity may have resulted from limited carbohydrate resources. Reduced root growth likely resulted in increased osmotic and nutrient deficiency stresses under saline conditions.

In summary, our data on turf quality, clipping yield, verdure, and root mass indicate that salinity damage becomes more severe as mowing height decreases. Moderately increas- 

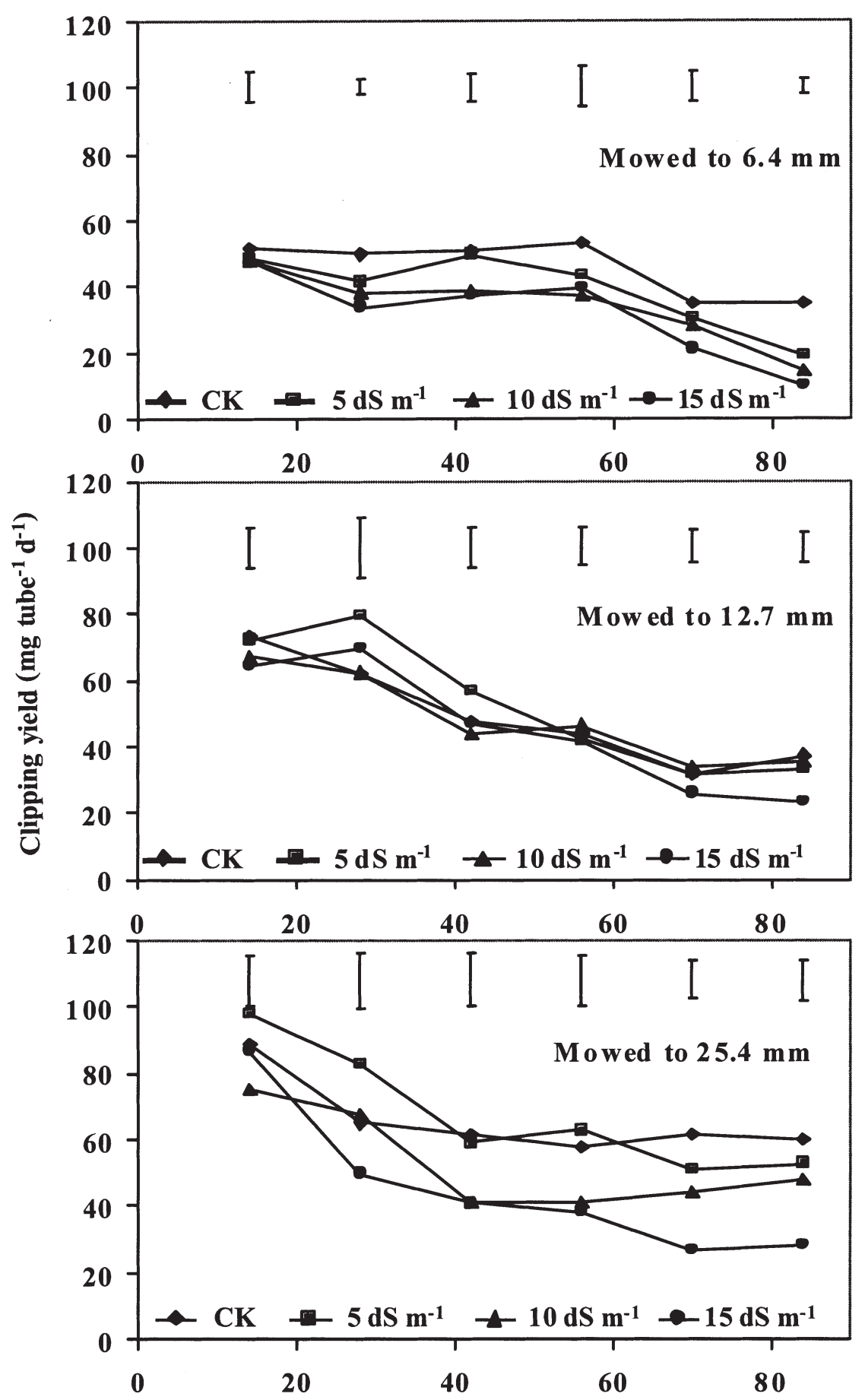

Days of treatment

ing mowing height could improve salinity tolerance of creeping bentgrass. The declining ability of bentgrass to tolerate salinity under close mowing may be associated with the effects of mowing height on photosynthesis and carbohydrate accumulation. Liu and Huang (2003) reported that low mowing significantly reduces the canopy photosynthetic rate of creeping bentgrass. Many salinity tolerance mechanisms require considerable amount of energy investment and are energy dependent. Further research is needed to determine photosynthetic rate, carbohydrate reserves, and other mechanisms that may attribute to the
Fig. 3. Influence of irrigation water salinity on clipping yield of creeping bentgrass at a given mowing height. Vertical bars indicate LSD value $(P=0.05)$ for salinity treatment comparison with a mowing height at a given day of treatment.

changing salinity tolerance under different mowing regimes.

\section{Literature Cited}

Beard, J.B. 1973. Turfgrass: Science and culture. Prentice-Hall, Englewood Cliffs, N.J.

Carrow, R.N., and R.R. Duncan. 1998. Salt-affected 

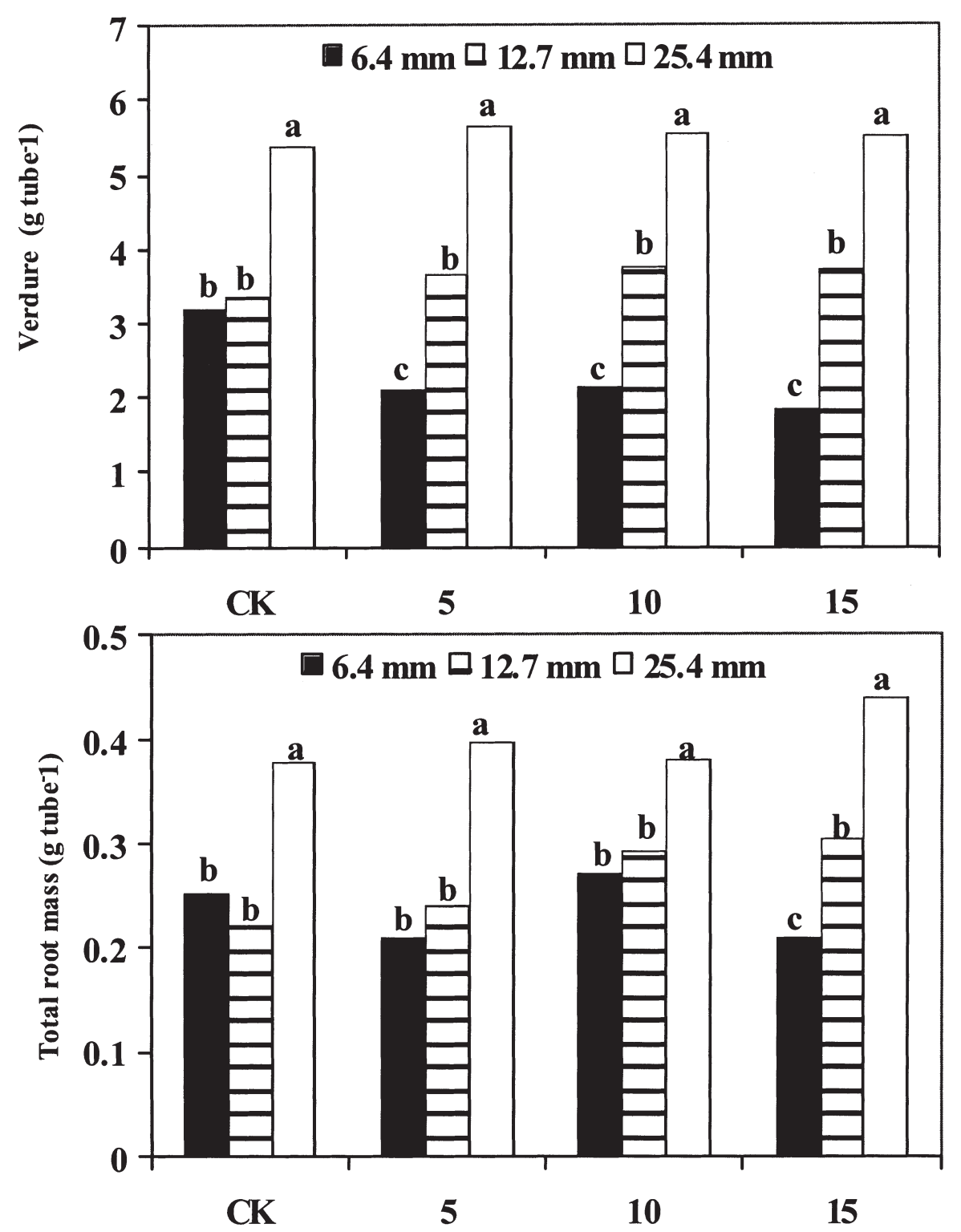

Salinity of ir rigation water $\left(\mathrm{dS} \mathrm{m}^{-1}\right)$

Table 2. Root mass at four depths for creeping bentgrass subjected to three mowing heights and irrigated by water at four different levels of salinity.

\begin{tabular}{lccccc}
\hline Soil & Mowing & \multicolumn{4}{c}{ Root mass $\left(\mathrm{mg} \cdot \mathrm{dm}^{-3}\right)$} \\
\cline { 3 - 5 } depth & ht & \multicolumn{4}{c}{ Salinity level $\left(\mathrm{dS} \cdot \mathrm{m}^{-1}\right)$} \\
\cline { 3 - 5 }$(\mathrm{cm})$ & $(\mathrm{mm})$ & $178.6 \mathrm{bA}^{2}$ & $162.5 \mathrm{aA}$ & $180.4 \mathrm{bA}$ & $163.9 \mathrm{cA}$ \\
\hline $0-10$ & 6.4 & $192.4 \mathrm{bB}$ & $190.7 \mathrm{aB}$ & $239.1 \mathrm{abAB}$ & $255.7 \mathrm{bA}$ \\
& 12.7 & $295.6 \mathrm{aA}$ & $287.0 \mathrm{aA}$ & $291.5 \mathrm{aA}$ & $334.9 \mathrm{aA}$ \\
& 25.4 & $43.5 \mathrm{bA}$ & $41.3 \mathrm{bA}$ & $48.6 \mathrm{bA}$ & $51.8 \mathrm{bA}$ \\
$10-20$ & 6.4 & $54.1 \mathrm{abA}$ & $64.7 \mathrm{bA}$ & $57.1 \mathrm{abA}$ & $63.8 \mathrm{bA}$ \\
& 12.7 & $81.5 \mathrm{aA}$ & $98.7 \mathrm{aA}$ & $84.2 \mathrm{aA}$ & $113.4 \mathrm{aA}$ \\
& 25.4 & $46.5 \mathrm{abB}$ & $39.5 \mathrm{abB}$ & $87.0 \mathrm{aA}$ & $35.1 \mathrm{bB}$ \\
$20-30$ & 6.4 & $20.2 \mathrm{bB}$ & $28.1 \mathrm{bAB}$ & $37.2 \mathrm{bA}$ & $32.3 \mathrm{abAB}$ \\
& 12.7 & $63.9 \mathrm{aA}$ & $49.7 \mathrm{aA}$ & $60.0 \mathrm{abA}$ & $54.2 \mathrm{aA}$ \\
$30-40$ & 25.4 & $40.8 \mathrm{aA}$ & $13.9 \mathrm{bB}$ & $19.4 \mathrm{aB}$ & $7.0 \mathrm{bB}$ \\
& 6.4 & $8.1 \mathrm{bA}$ & $11.8 \mathrm{bA}$ & $26.0 \mathrm{aA}$ & $26.5 \mathrm{aA}$ \\
& 12.7 & $25.1 \mathrm{abA}$ & $53.3 \mathrm{aA}$ & $37.0 \mathrm{aA}$ & $40.3 \mathrm{aA}$ \\
\hline
\end{tabular}

${ }^{2}$ Means in the same column followed by the small same letter within a column and means in the same row followed by the capital same letter are not significantly different at the 0.05 probability level.
Fig. 4. Influence of irrigation water salinity on verdure and total root mass of creeping bentgrass mowed to $6.4,12.7$, and $25.4 \mathrm{~mm}$, respectively. Columns marked with the same letters within a salinity treatment are not significantly different at the 0.05 probability level.

turfgrass sites: Assessment and management. Ann Arbor Press, Chelsea, Mich.

Devitt, D.A. 1989. Bermudagrass response to leaching fractions, irrigation salinity, and soil types. Agron. J. 81:893-901.

Dudeck, A.E., S. Singh, C.E. Giordano, T.A. Nell, and D.B. McConnell. 1983. Effects of sodium chloride on Cynodon turfgrasses. Agron. J. 75:927-930.

Harivandi, M.A., J.D. Butler, and L.Wu. 1992. Salinity and turfgrass culture, p. 208-230. In: D.V. Waddington et al. (eds.). Turfgrass. ASA-CSSA-SSSA (Madison, Wis.) Agron. Monogr. 32.

Hull, R.J. 1987. Kentucky bluegrass photosynthate partitioning following scheduled mowing. J. Amer. Soc. Hort. Sci. 112. 829-834.

Krans, J.V. and J.B. Beard. 1975. The effect of clipping height and frequency on several physiological and morphological responses in 'Merion' kentucky bluegrass. Agron. Abstr. 67:100.

Liu, X. and B. Huang. 2003. Mowing height effects on summer turf growth and physiological activities for two creeping bentgrass cultivars. HortScience 38:444-448.

Marcum. K.B. 1999. Salinity tolerance mechanisms of grasses in the subfamily chloridoideae. Crop Sci. 1999 39:1153-1160.

Marcum, K.B. 2001. Salinity tolerance of 35 bentgrass cultivars. HortScience 36:374-376.

Meyer, M.J., M. Smith, and S.L. Knight. 1989. Salinity effects on st. augustinegrass - A novel system to quantify stress response. J Plant Nutr. 12:893-908.

Peacock, C.H. and A.E. Dudeck. 1985. Physiological and growth responses of seashore paspalum to salinity. HortScience. 20:111-112.

Qian Y.L., R.F. Follett, S. Wilhelm, A.J. Koski, and M.A. Shahba. 2004. Carbon isotope discrimination of three kentucky bluegrass cultivars with contrasting salinity tolerance. Agron. J. 96:571-575.

Qian,Y.L., S.J. Wilhelm, and K.B. Marcum. 2001. Comparative responses of two kentucky bluegrass cultivars to salinity stress. Crop Sci. 41:1895-1900.

Rozema, J. and M. Visser. 1981. The applicability of the rooting technique measuring salt resistance in populations of festuca-rubra and juncus species. Plant and Soil 62:479-485.

Salaiz, T.A., G.L. Horst, and R.C. Shearman. 1995. Mowing height and vertical mowing frequency effects on putting green quality. Crop Sci. 35:1422-1425.

SAS Institute. 2001. SAS/STAT user's guide. ver. 6. 4th ed. SAS Inst., Cary, N.C.

Suplick-Ploense, M.R., Y.L. Qian, and J.C. Read. 2002. Salinity tolerance of texas bluegrass, kentucky bluegrass, and their hybrids. Crop Sci. 42:2025-2030.

Tester, M. and R. Davenport. 2003. $\mathrm{Na}^{+}$tolerance and $\mathrm{Na}^{+}$transport in higher plants. Ann. Bot. 91:503-527. 